\title{
PALEOPRODUCTIVITY CHANGES DURING THE LATE QUATERNARY IN THE SOUTHEASTERN BRAZILIAN UPPER CONTINENTAL MARGIN OF THE SOUTHWESTERN ATLANTIC*
}

\author{
Renata Hanae Nagai ${ }^{1 * *}$, Silvia Helena de Mello e Sousa ${ }^{2}$, Rafael André Lourenço ${ }^{l}$, \\ Márcia Caruso Bícego ${ }^{2}$ and Michel Michaelovitch de Mahiques ${ }^{2}$ \\ ${ }^{1}$ Instituto Oceanográfico da Universidade de São Paulo \\ Programa de Pós-graduação em Oceanografia Química e Geológica \\ (Praça do Oceanográfico, 191, 05508-120 São Paulo, SP, Brasil) \\ ${ }^{2}$ Instituto Oceanográfico da Universidade de São Paulo \\ Departamento de Oceanografia Física, Química e Geológica \\ (Praça do Oceanográfico, 191, 05508-120 São Paulo, SP, Brasil) \\ ***Corresponding author: renatanagai@usp.br
}

\section{A B S T R A C T}

Changes in the Brazilian continental margin's oceanic productivity and circulation over the last 27,000 years were reconstructed based on sedimentological and microfaunal analyses. Our results suggest that oceanic paleoproductivity and the supply of terrigenous sediments to the Brazilian continental margin were higher during the Last Glacial Maximum (LGM) than during the Holocene. These changes may have been primarily influenced by significant sea level fluctuations that have occurred since the late Pleistocene. During the LGM, the lower sea level, higher productivity and lower sea-surface paleotemperatures may have been the result of the offshore displacement of the main flow of the Brazil Current. However, during the Holocene, the warm waters of the Brazil Current were displaced toward the coast. This displacement contributed to the increase in water temperature and prevented an increase in oceanic productivity. The decrease in terrigenous supply since the LGM could be related to the increase of the extension of the continental shelf and/or drier climatic conditions.

\section{R ESUMO}

Mudanças na produtividade e circulação oceânica da margem continental Brasileira foram reconstituídas a partir de análises sedimentológicas e microfaunísticas realizadas em sedimentos de um testemunho representativo dos últimos 27000 anos. Nossos dados sugerem maior produtividade oceânica e suprimento de sedimento terrígeno na área de estudo no Último Máximo Glacial (UMG) do que no Holoceno. Estas mudanças foram principalmente influenciadas por flutuações do nível relativo do mar. Durante o UMG, num cenário de nível relativo do mar mais baixo, a maior produtividade oceânica e menor temperatura da superfície do mar, podem ter sido produtos do deslocamento para o largo da Corrente do Brasil. No Holoceno, o deslocamento para a costa das águas quentes da Corrente do Brasil contribuiu para o aumento na temperatura da água e menor produtividade oceânica. A diminuição do aporte de sedimentos terrígenos desde o UMG pode estar relacionado ao aumento da extensão da plataforma continental e/ou a condições climáticas mais secas no continente.

Descriptors: Foraminifera, Brazil Current, Late Quaternary, Southwestern Atlantic.

Descritores: Foraminiferos, Corrente do Brasil, Quaternário Tardio, Atlântico Sudoeste.

\section{INTRODUCTION}

Understanding the mechanisms that influence the balance of carbon between oceans and

(*) Paper presented at the INTERNATIONAL GEOLOGICAL CORRELATION PROGRAM PROJECT NO. 526 - RISKS, RESOURCES, AND RECORD OF THE PAST ON THE CONTINENTAL SHELF: MINING LATE QUATERNARY GEOLOGICAL EVIDENCE, 2., 2008, Natal, UFRN. the atmosphere is one of the main goals of modern science, due to the social and economic impacts of global warming. Oceanic productivity plays an important role in this balance. For instance, it has been proposed that increased strength and efficiency of the oceanic biological pump is one of the mechanisms responsible for lower atmospheric $\mathrm{CO}_{2}$ concentrations during the Last Glacial period (i.e., BROECKER; PENG, 1986; SARNTHEIN et al., 1988; MIX, 1989). 
The Last Glacial Maximum (LGM) is the largest manifestation of natural climate change that remains relatively well preserved in the geological record, and understanding it represents a long-standing goal of paleoclimatologists (MIX et al., 2001).

Few studies that focus on the LGM have been developed in the Brazilian continental margin, and the studies that have been conducted have concerned processes such as oceanic circulation and productivity linked to climatic changes (i.e., MOLLENHAUER et al., 2004; CLAUZET et al., 2007; TOLEDO et al., 2007a, 2008; MAHIQUES et al., 2007).

Based on planktonic microfossils, Toledo et al. (2007a; 2008) found evidence of increased productivity during the LGM and during the deglaciation. Toledo et al. (2007a) speculated that benthic communities would be favored by this increase in productivity. Additionally, Mahiques et al. (2007) reported an increase in productivity during the LGM in the upper slope of the Southeastern Brazilian continental margin. However, they attributed this difference in productivity to changes in oceanic circulation related to mean sea-level fluctuations. Higher organic carbon accumulation during the LGM might also be related to changes in bottom water circulation, and not just the enhancement of the exported productivity (MOLLENHAUER et al., 2004).

Foraminifera are widely employed as proxies in paleoceanographic reconstructions (i.e., HERGUERA; BERGER, 1991; EBERWEIN; MACKENSEN, 2008; TOLEDO et al., 2008). These

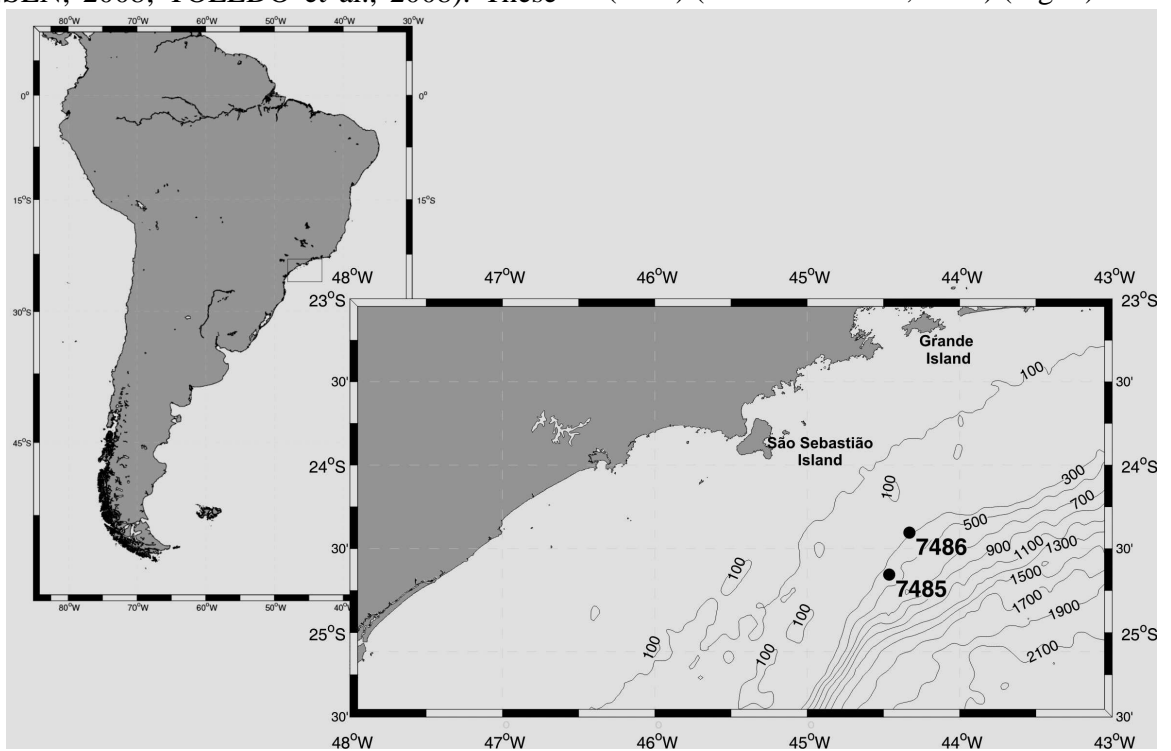

Fig. 1. Location map of the study area in southeastern Brazil, State of São Paulo, with location of the oceanographic stations where core 7486 (this study) and 7485 (Mahiques et al., 2007) were collected. planktonic or benthic shelled organisms change their distribution, community structure and standing stocks in response to environmental changes (i.e., temperature, organic carbon flux to the sea floor, bottom current velocity, etc.). For example, the distribution of benthic foraminifera is mainly controlled by the variability of organic carbon flux to the sea floor in terms of quantity and quality of organic matter, as well as by redox conditions at the sediment-water interface and in the sedimentary porewaters (LOUBERE; FARIDUDDIN, 1999; HERGUERA; BERGER, 1991; SCHMIEDL et al., 2000; FONTANIER et al., 2002). Planktonic foraminifera distribution and abundance is controlled by multiple biotic and abiotic factors, including food availability, predation, algal symbionts, light, temperature, salinity, turbidity and circulation (HEMLEBEN et al., 1989).

The aim of this study was to evaluate the use of a multi-proxy (sediment and microfossil) approach in order to better understand oceanic productivity and circulation changes that occurred in the Southeastern Brazilian continental margin during the Late Quaternary.

\section{Present Oceanographic Conditions}

The study area comprises the shelf break region of the Southeastern Brazilian continental margin. Specifically, the study was carried out in the morphologic sector known as São Paulo Bight that extends from Cabo de Santa Marta $\left(28^{\circ} \mathrm{S}\right)$ to Cabo Frio $\left(23^{\circ} \mathrm{S}\right)$ (ZEMBRUSCKI, 1979) (Fig. 1). 
The oceanic circulation processes in the study area are dominated by the Brazil Current (BC). This current flows southward and meanders around the 200 meter isobath (CAMPOS et al., 2000). The BC transports Tropical Water $\left(\mathrm{TW}, \mathrm{T}>20^{\circ} \mathrm{C}\right.$ and $\mathrm{S}>$ 36.40) at upper levels and South Atlantic Central Water (SACW, $\mathrm{T}<20^{\circ} \mathrm{C}$ and $\left.\mathrm{S}<36.40\right)$ at pycnocline levels (SILVEIRA et al., 2000; MAHIQUES et al., 2002).

According to Campos et al. (2000), the BC develops a convoluted meandering pattern around the Cabo Frio area, mainly due to the change in orientation of the Brazilian coastline. The clockwise meander formed in this process is also associated with the seasonal cycle of prevailing NE winds. This combination establishes shelf break upwelling along the SE Brazilian continental margin (CAMPOS et al., 2000). During summer, the dominant NE wind direction favors Coastal Water (CW) movement offshore and the subsurface penetration of the SACW to shallower areas (CASTRO, 1996). In the São Sebastião Island area, the movement of the CW offshore causes the transport of suspended terrigenous material to the outer shelf (MAHIQUES et al., 1999).

On the middle shelf, outer shelf and upper slope, the sedimentary processes are influenced by the flow of the BC along the western Atlantic continental margin (MAHIQUES et al., 2002, 2004). The BC has a "floor polisher effect" that leads to a sea bottom where coarse sands, carbonate gravel and boulder prevail. Radiocarbon dating has led to the identification of a relict facies beyond the 140 meter isobath (MAHIQUES et al., 2002).

\section{Past Oceanographic Conditions}

The Brazilian continental margin has experienced relative sea level (RSL) changes during the Last Glacial Cycle that were caused by glacioeustasy. According to Giannini et al. (2007), at least two phases of rise and highstands linked to Quaternary global glacioeustatic changes have been recorded in the RSL change curves calculated for the Brazilian coast (Fig. 2). The oldest high phase occurred in the Last Interglacial period (approximately $120 \mathrm{kyr}$ BP) when the RSL reached $8 \pm 2 \mathrm{~m}$ above the present sea level (MARTIN et al., 1988). The oldest low phase occurred during the Last Glacial Maximum (approximately $18 \mathrm{kyr}$ BP) when the RSL was approximately $130 \mathrm{~m}$ below the present level (CORRÊA, 1996).

According to Toledo et al. (2007b), only moderate sea surface temperature (SST) changes (approximately $\sim 2^{\circ} \mathrm{C}$ occurred in the Brazilian continental margin in the past 25 kyr. Toledo et al. (2007b) also reported the occurrence of higher temperatures in the Holocene (between 26 and $27.5^{\circ} \mathrm{C}$ ) than in the LGM (approximately $25.5^{\circ} \mathrm{C}$ ). According to some authors (e.g., LEDRU et al., 2005; JACOB et al., 2007; SYLVESTRE, 2009), moisture conditions in South America were higher in the LGM than in the Holocene. These humid conditions are attributed to the intensification and/or a southern shift of the Intertropical Convergence Zone (ITCZ) across northern Brazil (JACOB et al., 2007). Higher moisture rates were also reported by Ledru et al. (2005) for southern Brazil, probably reflecting a displacement of the circum-polar vortex toward the equator. This displacement may have induced a northern shift of the westerlies on the Pacific side of South America and the polar jets on the Atlantic side of South America.

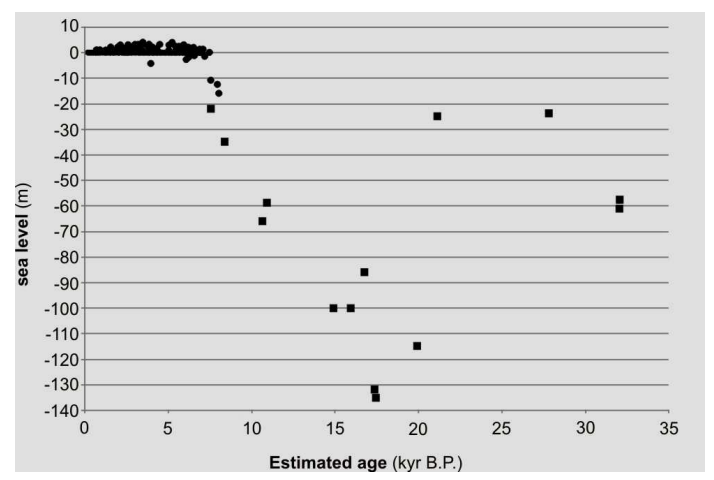

Fig. 2. RSL (Relative sea level) curve for the Brazilian continental margin in the last 35000 years for the Brazilian coastal zone and adjacent continental shelf (after Angulo et al., 2006 (circles); Correa, 1996 (squares)).

The Brazilian continental margin oceanic circulation was influenced by both climatic changes and RSL fluctuations during the LGM. According to Clauzet et al. (2007), the subtropical gyre intensified, and the South Equatorial Current (SEC) bifurcation shifted north during the LGM. This northern shift of the SEC was a result of a northern shift of the Subtropical Convergence Zone (CLAUZET et al., 2007). These changes led to the increased intensity of southern transport by the BC and its associated BC recirculation cell in the southern Atlantic basin (CLAUZET et al., 2007).

Changes in oceanic circulation have been derived from RSL fluctuations for the Campos Basin continental margin (VIANA et al., 1998), which is north of our study area. During the last RSL lowstand, sedimentary and oceanographic processes experienced a basin-wide shift that was accompanied by changes in the facies related to ocean circulation (i.e., sandy contourites to shallow-water bottom-current sands). 


\section{Materials ANd Methods}

This study is based on the analysis of the piston core 7486, collected at the southeastern Brazilian upper continental margin. This core was collected during a 2003 oceanographic survey on board the R.V. Prof W. Besnard (Oceanographic Institute of University of São Paulo). The core was collected at $24^{\circ} 24.24^{\prime} \mathrm{S}$ and $044^{\circ} 19.80^{\prime} \mathrm{W}$ in 223 meters of water $(96 \mathrm{~cm}$ recovery). Magnetic susceptibility measurements were performed on board using a Bartington MS2C Sensor. The core was sampled continuously at $2 \mathrm{~cm}$ intervals, and sediment samples were frozen and subsequently freeze-dried.

The age model for core 7486 was based on five AMS radiocarbon sediment dating (Table 1). All datings were performed at Beta Analytic Inc. (USA). The SW Atlantic Reservoir correction $(\Delta \mathrm{R}=87, \mathrm{U}=$ 46 , corresponding to the average value of the three samples from that reported area; ANGULO ET AL., 2005) was applied to the samples. The age-depth relationship was obtained by using the cubic-spline approach and the age-model of sedimentation rates values.

Grain size was determined from decarbonated samples using a Malvern Masterizer 2000 analyzer. Carbonate content was calculated by the difference in weight prior to and after acidification (using a 10\% hydrocholoric acid solution) of $2 \mathrm{~g}$ of the sample. Organic carbon and total nitrogen were determined using a LECO CNS2000 analyzer.

The foraminiferal contents of Core 7486 were also investigated. Samples of $10 \mathrm{~cm}^{3}$ were taken $5 \mathrm{~cm}$ apart along the core. These samples were washed through a set of $125 \mu \mathrm{m}$ and $63 \mu \mathrm{m}$ sieves. The sample fraction greater than $125 \mu \mathrm{m}$ was examined for its benthic foraminifera content. Samples were split and sorted until a minimum of 300 foraminifera specimen had been counted. This process provided foraminifera abundance data. Tests for benthic foraminifera analysis were identified based on previous literature (e.g., VAN MORKHOVEN, 1986; LOEBLICH; TAPPAN, 1988; JONES, 1994; BARBOSA, 1998).

For planktonic foraminiferal analysis, the ratio between two species, Globigerinoides ruber and Globigerina bulloides, was obtained in the sample fraction greater than $125 \mu \mathrm{m}$. Tests were identified based on Hemleben et al. (1989).

\section{Productivity and Temperature Proxies}

Considering that benthic foraminifera are sensitive to changes in organic carbon flux, oxygenation and near-bottom current velocity, we used two benthic foraminifera indices to identify periods characterized by a higher supply of organic carbon to the sea floor. The Benthic Foraminifera
High Productivity (BFHP) index is based on the total percentage of species related to a high flux of organic matter (adapted from Martins et al., 2007). The Benthic Foraminifera Accumulation Rate (BFAR) index is represented as tests $\bullet 10 \mathrm{~cm}^{-2} \bullet \mathrm{ka}^{-1}$ (adapted from Wollenburg and Kuhnt, 2000). The BFAR index is commonly applied to deep-sea sites and is correlated with the exported organic carbon flux to the sea floor. Therefore, the index is correlated with primary production. However, the BFAR index has limitations such as the dependence on sedimentation rates and the assumption that lateral supply of organic carbon is low or absent. Thus, the BFAR index should be applied to paleoproductivity change and trend studies with caution.

Basin-wide mapping of sea-surface paleotemperatures are commonly estimated based on species abundance of fossil plankton and on organic geochemistry (i.e., alkenone unsaturation indices, typically $\mathrm{U}^{\mathrm{k}^{\prime}}{ }_{37}$; MIX et al., 2001). Thus, to better understand the possible changes in paleotemperature, we examined the ratio between two planktonic foraminifera species $(G$. ruber and $G$. bulloides) and compared these data with unpublished alkenones-based temperature data calculated for core 7485 (collected at $24^{\circ} 39.27^{\prime} \mathrm{S}$ and $044^{\circ} 27.74^{\prime} \mathrm{W}$; Figure 1).

The G. ruber/G. bulloides ratio was calculated by modifying methodology proposed by Toledo et al. (2008). The ratio is considered to be both a paleotemperature and paleoproductivity proxy. This qualitative proxy is based on the fact that the broadscale distribution of planktonic foraminifera is mainly related to water temperature and strongly influenced by nutrient availability (KEMLE-VON MÜCKE; HEMLEBEN, 1999; MOREY et al., 2005). Therefore, higher $G$. ruber/G. bulloides values reflect periods of a stronger influence by warm and oligotrophic tropical waters, and lower $G$. ruber/G. bulloides values reflect periods of a stronger influence by colder and nutrientricher waters.

\section{Results}

Core 7486 covered an age range of $27 \mathrm{cal}$ kyr (Table 1; Figure 3), with no observed age inversion in the radiocarbon datings. Holocene sediments were found only in the first $10 \mathrm{~cm}$ of the sedimentary column. These results revealed a sedimentation rate of $0.001 \mathrm{~cm} . \mathrm{yr}^{-1}$ for the period. Most of the sedimentary column (sedimentary depth of approximately $10 \mathrm{~cm}$ to $74 \mathrm{~cm}$ ) represented an age range of 11 to $25 \mathrm{cal}$. kyr $\mathrm{BP}$ and presented higher sedimentation rates (average $0.011 \mathrm{~cm} . \mathrm{yr}^{-1}$ ). From 25 to 27 cal. kyr BP, sedimentation rates remained constant (Fig. 4). 
Table 1. Results of radiocarbon dating determined for core 7486 in the Laboratory Beta Analytic Inc. (Miami, FL USA).

\begin{tabular}{ccc}
\hline \hline Depth $(\mathrm{cm})$ & BETA number & $\begin{array}{c}\text { Conventional } \\
\text { Radiocarbon Age } \\
\text { (yr B.P.) }\end{array}$ \\
\hline 1 & 215807 & $2840 \pm 50$ \\
21 & 215808 & $19110 \pm 90$ \\
41 & 215809 & $22890 \pm 140$ \\
71 & 215810 & $26030 \pm 190$ \\
95 & 215811 & $25790 \pm 180$ \\
\hline
\end{tabular}

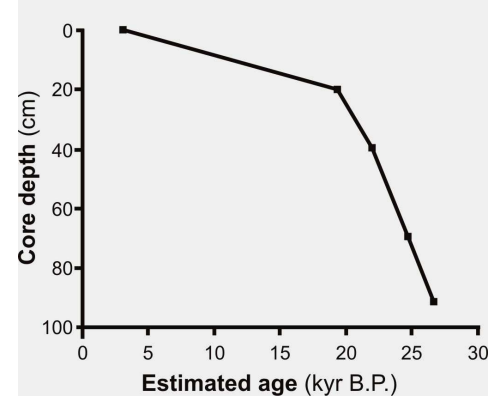

Fig. 3. Age-depth model for core 7486, squares represent AMS radiocarbon dates.

Magnetic susceptibility changes were observed between Pleistocene and Holocene sediments. Higher values of magnetic susceptibility were found in sediments older than 18 cal. kyr Grain size distribution, represented by median size (in $\mu \mathrm{m}$ ), and sand content $(\%)$ presents a trend of coarsening from the LGM (average median of 32 $\mu \mathrm{m}$ and approximately $20 \%$ of sand) toward the Holocene (average median of $70 \mu \mathrm{m}$ and more than $64 \%$ of sand) (Fig. 4). We also observed low calcium carbonate concentration values (approximately 11\%) in LGM sediments, with concentrations increasing post-LGM (average of 36\% in post-LGM sediments).

Similar to the calcium carbonate concentration trend, the benthic foraminiferal density (number of specimens in $10 \mathrm{cc}$ of sediment) also increased in post-LGM sediments. Values ranged between 96 and 62,720 tests (Fig. 5). A total of 168 taxa were recognized (Appendix). These specimens were mainly calcareous, with no apparent evidence of dissolution or shattered chambers in the sediments (which could be caused by freeze-drying after sediment sampling).

Eleven species had frequencies higher than $3 \%$ in at least $10 \%$ of samples and were considered "representative species." Their distribution along the sedimentary column is represented in Figure 6.

Between 10 and 25 cal. kyr, higher frequencies of the infaunal species Bulimina marginata, Islandiella norcrosi and Uvigerina peregrina were observed. Species frequencies of epifauna (Cibicidoides wuellerstorfi, Cibicidoides spp. and Planulina ariminensis d' Orbigny 1826) and shallow infauna (Cassidulina spp., Globocassidulina subglobosa and Globocassidulina spp.) increased in the post-LGM sediments. In contrast, Cibicides spp. and Ehrenbergina spinea had consistently low frequencies throughout the entire core (only $2 \%-3 \%$; Fig. 6).

During the LGM, the presence of $B$. marginata and $U$. peregrina (Fig. 6) was accompanied by higher BFHP and BFAR values $(29 \%$, at 23,000 cal. yr BP and approximately 92,922 tests $\bullet \mathrm{cm}^{-2} \cdot \mathrm{ka}^{-1}$, respectively; Fig. 5).

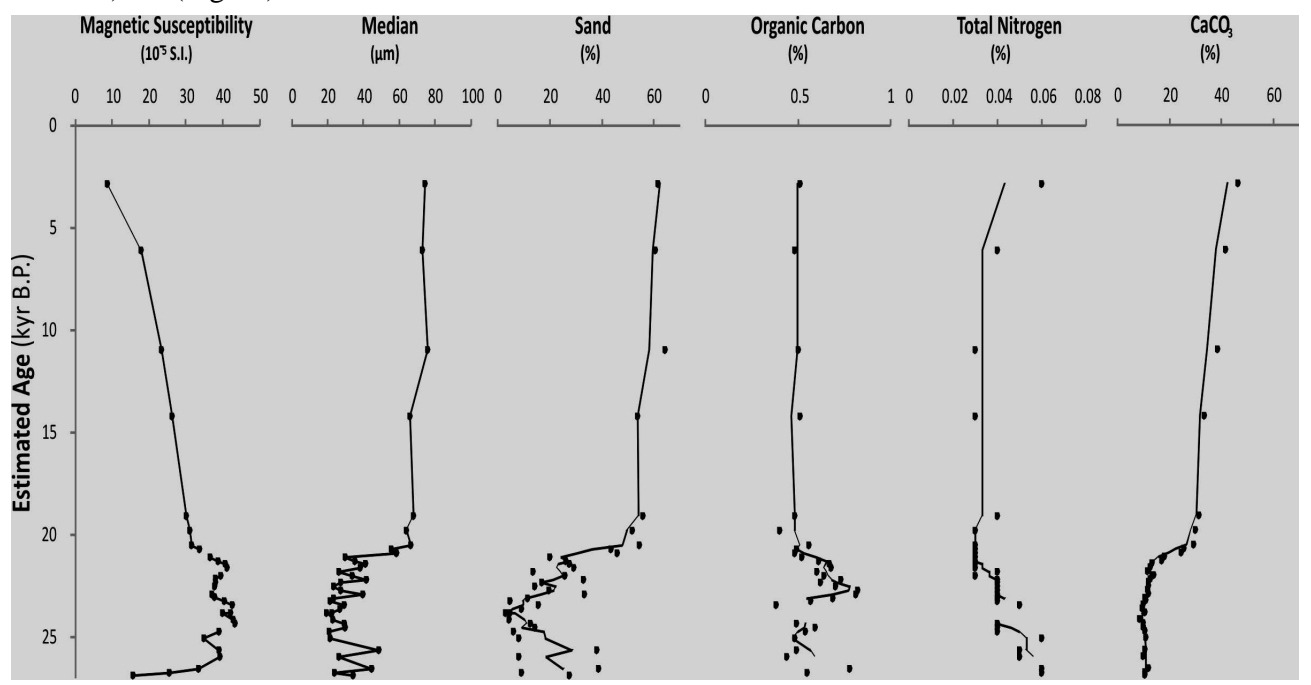

Fig. 4. Along-core distribution of magnetic susceptibility, grain size (median and sand content), calcium carbonate $\left(\mathrm{CaCO}_{3}\right)$, organic carbon and total nitrogen contents for core 7486 . 


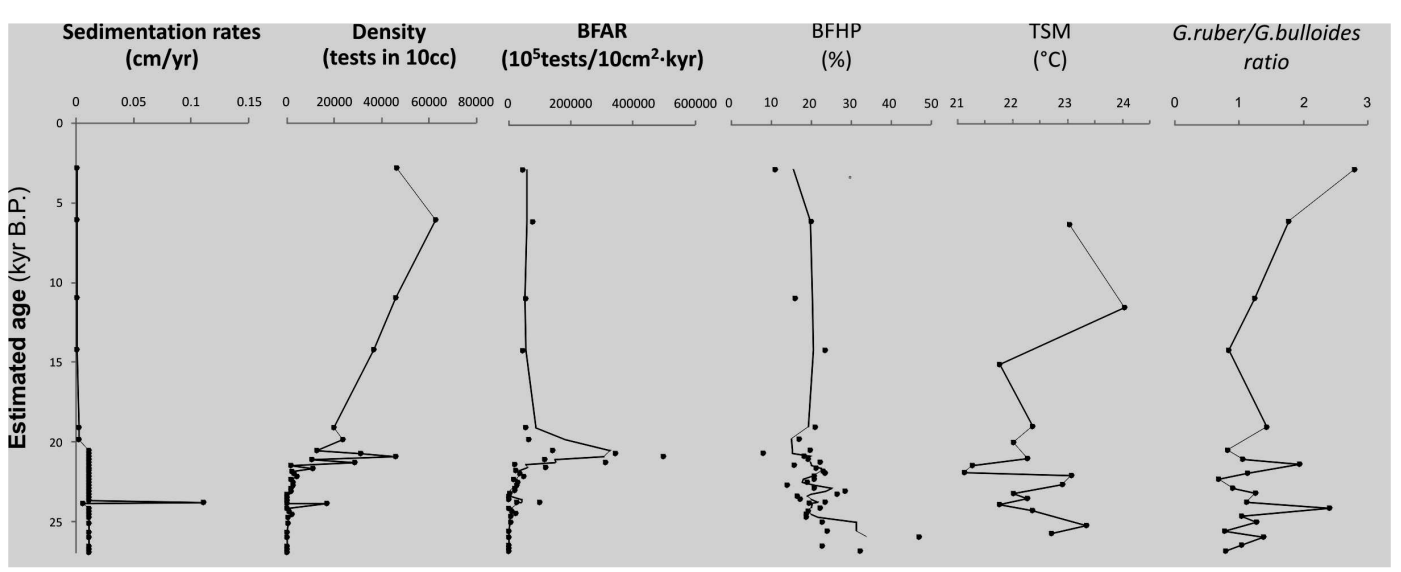

Fig. 5. Along-core distribution of sedimentation rates, benthic foraminifera density, and indexes BFAR (Benthic Foraminifera Accumulation Rates) and BFHP (Benthic Foraminifera High Productivity), indicating a decrease in productivity towards present time and relatively higher productivity during the Pleistocene; and alkenone based SSTs (Sea Surface Temperatures) estimated for core 7485 (unpublished data) and G.ruber/G.bulloides ratio for core 7486, suggesting an overall increase in SSTs towards present time.

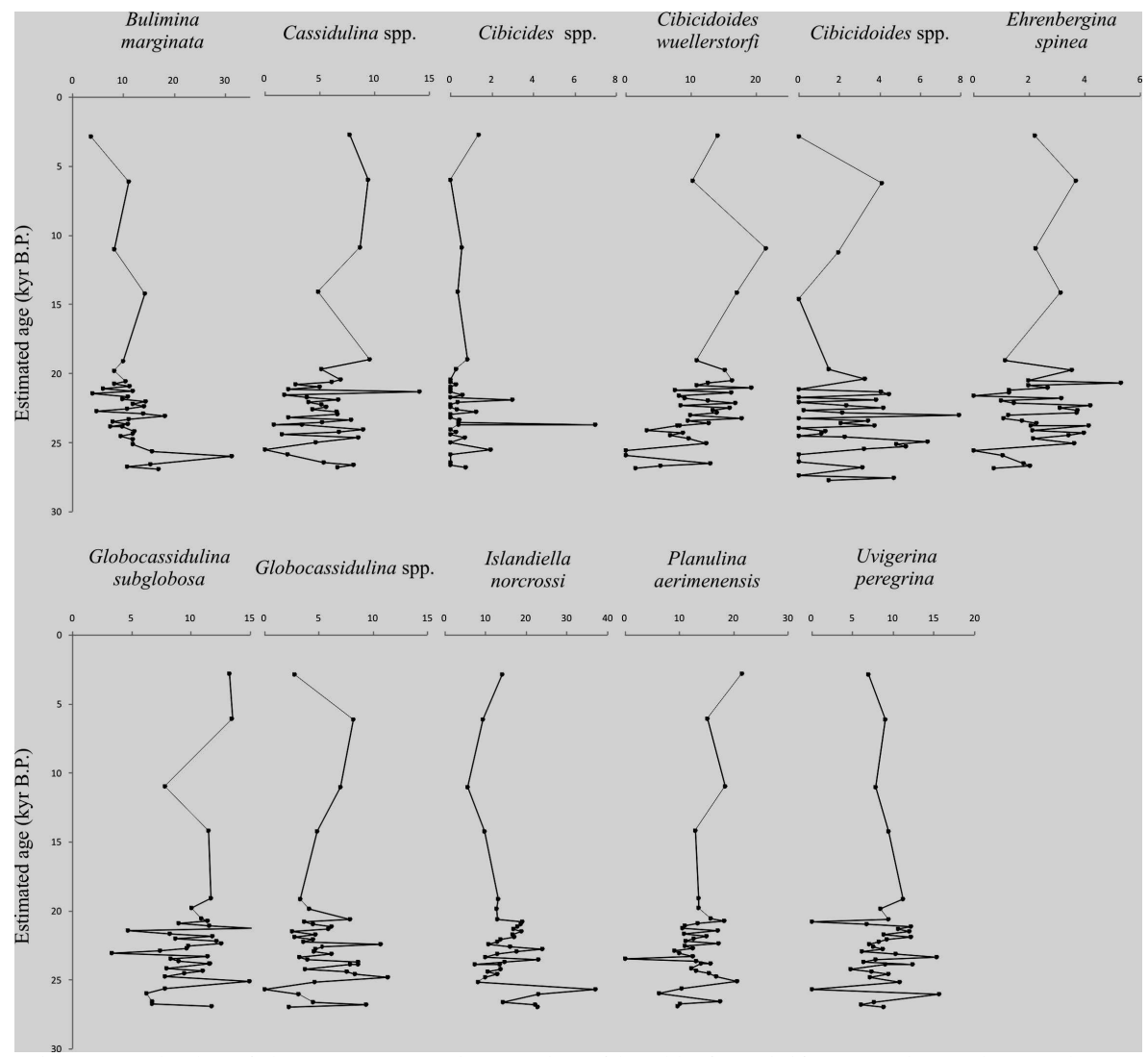

Fig. 6. Depth plot of the 11 representative species of benthic foraminifera. Species such as Bulimina marginata, Islandiella norcrosi and Uvigerina peregrina present higher frequencies in IS2 sediments. Whereas species such as Cassidulina spp., Cibicidoides wuellerstorfi, Cibicidoides spp., Globocassidulina subglobosa, Globocassidulina spp. and Planulina ariminensis are more represented in coarser sediments increasing their frequencies in post-LGM sediments. 
The frequencies of infaunal species, the productivity proxies (BFAR and BFHP), and organic carbon contents diminished in post-LGM sediments. For example, organic carbon contents ranged from $0.60 \%$ ( 20,540 cal. yr BP) to $0.51 \%$ in Holocene sediments (Fig. 4). Low values of nitrogen in the sediments during this interval resulted in anomalously high $\mathrm{C} / \mathrm{N}$ ratios. Post-LGM sediments were also characterized by higher frequencies of shallow infaunal and epifaunal benthic foraminifera species $G$. subglobosa, C. wuellerstorfi and P. ariminensis (Fig. 6). Pleistocene samples had an average $G$ ruber/G. bulloides ratio of 1.3. This ratio increased toward present time (Fig. 5).

\section{Discussion}

Sedimentation rates appear to have been higher during the LGM, with a decrease toward present time. This could be related to a more effective action of the BC during the Holocene. This hypothesis was proposed by Mahiques et al. (2007) based on the analysis of sedimentological data from core 7485 (see Figure 1 for location). Thus, an evident change in the sedimentation pattern of the study area marks the LGM-Holocene transition. This change is also observed in the magnetic susceptibility, sedimentological and microfaunal data when Holocene and Late Pleistocene sediments are compared.

Magnetic susceptibility changes between Pleistocene and Holocene sediments reflect changes in the terrigenous input pattern in the study area in the last 27,000 years. Higher values of magnetic susceptibility indicate a higher input of terrigenous sediments during the LGM. This higher terrigenous input could be function of: (i) lower RSL conditions (CORRÊA, 1996) that decreased the distance between core site and terrigenous sediment source and/or (ii) more humid climatic conditions over the continent during the LGM (see Sylvestre, 2009 for a review). We favor lower RSL conditions as the predominant factor influencing the increase in terrigenous input at core sites. Humid climatic conditions may be a secondary factor, since more humid climatic conditions have been reported as a source of higher terrigenous input during the LGM (ARZ et al., 1998).

Unfortunately, the origin of the organic matter cannot be confirmed by $\mathrm{C} / \mathrm{N}$ ratio values, due to the low correlation between organic carbon and total nitrogen $(r=0.04)$. This low correlation does not guarantee the organic character of the nitrogen. The hypothesis that low calcium carbonate concentrations observed during the LGM can be attributed to dilution by terrigenous sediments (ARZ et al., 1998; MAHIQUES et al., 2007) also supports higher terrigenous input during this period.
During the LGM, the presence of species that were considered to be indicative of high food availability in the environment (B. marginata and $U$. peregrina; see Martins et al., 2007 for a review) suggests higher input of organic matter to the benthic environment. This is supported by the higher BFHP and BFAR values in LGM sediments (Fig. 5).

Increased benthic productivity is also supported by the higher organic carbon contents in LGM sediments.

The planktonic foraminifera (reflected in the G. ruber/G. bulloides ratio) apparently responded to both productivity and temperature variations. Our data show a positive relationship between the G. ruber/G. bulloides ratio and alkenone-based SST estimates over the last $27 \mathrm{kyr}$. This relationship enables us to infer that the Brazilian continental margin experienced changes in SST during the LGM. Fossil plankton and organic geochemistry proxies support that there were lower SSTs during the LGM than during the present time. Additionally, higher calcium carbonate contents in Holocene sediments support a warmer scenario during this period (ARZ et al., 1998). These findings are in accordance with the results of Toledo et al. (2007b). These authors found a sharp decrease of SST by approximately $2^{\circ} \mathrm{C}$ at 21,000 years BP based on planktonic foraminifera data and reconstructed SST for the Southwestern South Atlantic.

The G. ruber/G. bulloides ratio also suggests the occurrence of a stronger influence of warm and oligotrophic tropical waters in the study area after the LGM. This strong influence of warmer waters, coupled with the trend of grain-size coarsening toward the Holocene, suggests changes in the study area's hydrodynamic regime. These changes should have been induced by RSL variations. The change in SST observed in our data is also in accordance with a model proposed by Mahiques et al. (2007). This model states that the offshore displacement of the BC under low sea-level conditions resulted in a less intense action of the $\mathrm{BC}$ on the outer shelf and upper slope (Fig. 7). We found that during higher RSL conditions, the upper slope was once again covered by the warm waters of the BC (Fig. 7). This, in turn, would have prevented the increase of oceanic productivity during the Holocene.

In a large scale modeling study, Clauzet et al. (2007) reported a strengthening in the flow of the $\mathrm{BC}$ during the LGM as a consequence of changes in large scale atmospheric processes. However, changes in the intensity of the BC flow in the Southeastern Brazilian continental margin might not be recorded in our cores if this current displaced offshore during the LGM.

The increased input of organic matter during the LGM might have been caused contributed by BC's diminished capability of sediment remobilization 
(MAHIQUES et al., 2007) leading to higher rate of organic carbon sediment entrapment. In contrast, the post-LGM sediments have lower infaunal species frequencies, lower productivity proxies (BFAR and BFHP) and lower organic carbon contents. This suggests diminished productivity. Toledo et al. (2008) also found a decrease in the productivity through the Holocene. They attributed this decrease to a progressive strengthening of the $\mathrm{BC}$ as a result of a southern displacement of the ITCZ, due to insolation changes related to the precessional cycle (TOLEDO et al., 2008). Mahiques et al. (2007) found that this decrease in productivity was due to a displacement of the $\mathrm{BC}$ towards land, resulting in a more intense action of the current in the upper slope and outer shelf of the Southeastern Brazilian continental margin (Fig. 7). Thus, the maintenance of the $\mathrm{BC}$ warm waters on the upper slope would have prevented a higher productivity during the Holocene.

Grain size distribution also points to more intense action of the $\mathrm{BC}$ in the study area after the
LGM. Post-LGM sediments are characterized by higher frequencies of shallow infaunal and epifaunal benthic foraminifera species, such as G. subglobosa, $C$. wuellerstorfi and $P$. ariminensis. These species are usually found inhabiting coarser sediments and environments with low nutrient availability, and thus are considered proxies of strong bottom currents (MURRAY, 1991; MACKENSEN et al., 1995; SCHMIEDL; MACKENSEN, 1997; MARTINS et al., 2007). This decrease in productivity in the time postLGM is also supported by higher $G$. ruber/G. bulloides ratios.

Apparently, the change in water temperature during the LGM was not restricted to the superficial layers of the water column. During this interval, the presence of the infaunal benthic foraminifera species $I$. norcrosi is noted. This species is generally found inhabiting low temperature environments (MURRAY, 1991). We found a positive relationship with both benthic foraminifera productivity and geochemical temperature proxies. (a)

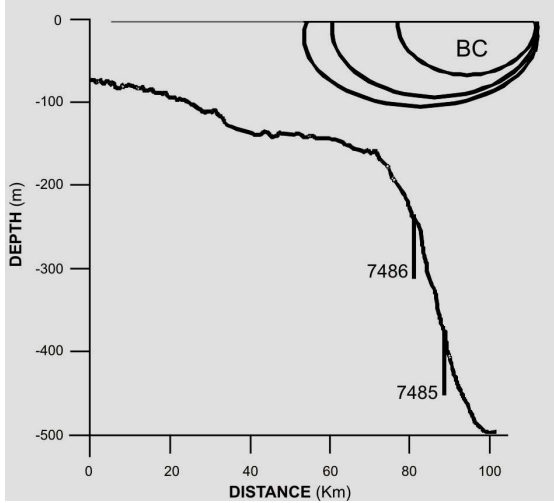

(b)

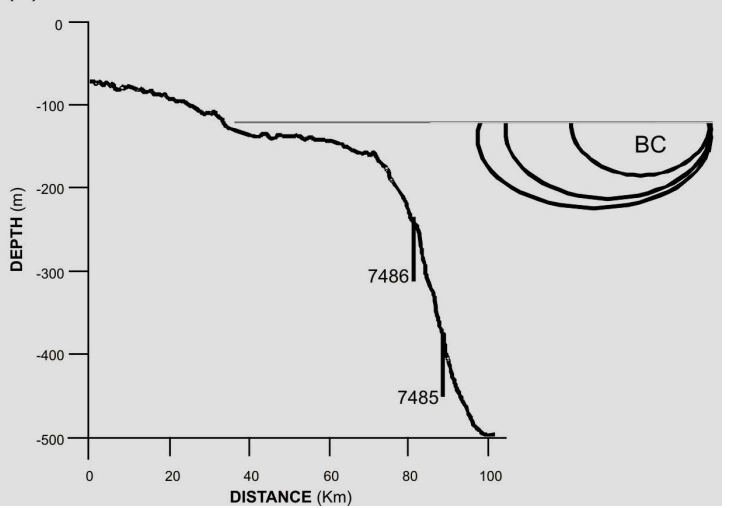

Fig. 7. Schematic model showing cores 7486 (this study) and 7485 (Mahiques et al., 2007) positions, and the position of the Brazil Current (BC) under different climatic conditions (a) Present and Isotope Stage 3 and (b) Last Glacial Maximum. (Modified from: Mahiques et al., op cit.).

During the LGM, humid climatic conditions could have increased terrigenous sediment input, thereby influencing water turbidity, decreasing water column light penetration, and altering sea surface salinity.

Salinity changes have also been reported for the Southwestern Atlantic in the last $30 \mathrm{kyr}$ (see Toledo et al., 2007a for a review). Based on three cores from the Southeastern Brazilian continental margin, Toledo et al. (2007a) reported higher sea surface salinity values. These values were highest between 22 and $28 \mathrm{kyr}$ BP and gradual decreased during the Holocene. The observed salinity variations were related to hydrological balance and global circulation (TOLEDO et al., 2007a). However, the planktonic and benthic foraminifera record (community structure) in our core does not point to salinity changes in the study area over the last 27,000 years.

\section{Conclusions}

Our multiproxy analysis integrating sedimentological, geochemical and microfaunal proxies highlights changes in oceanic productivity and circulation in the Brazilian southeastern upper continental margin. These changes were strongly influenced by RSL fluctuations that occurred in the 
Late Quaternary. During the LGM, higher input of terrigenous sediments and the increase in productivity were due to the offshore displacement of the $\mathrm{BC}$, as a consequence of lower RSL conditions, and to humid climatic conditions over the continent. In contrast, during the Holocene (a period of higher RSL), the increase in water column temperature and more intense action of the $\mathrm{BC}$ suggest a displacement of the warm waters of the Brazil Current toward the coast. This displacement prevented the increase in water productivity. Our findings support the conceptual model proposed by Mahiques et al. (2007).

\section{ACKNOWLedGEMENTS}

The authors wish to acknowledge the crew of the R.V. "Prof. W. Besnard" and the researchers who joined the "Buzios project" cruise in September 2003 and Thaisa Marques for her help in manufacturing the location map figure. This manuscript was substantially improved by the comments of two anonymous reviewers. Financial support was provided by the Fundação de Amparo à Pesquisa do Estado de São Paulo (FAPESP) through grants 01/13490-9 and 04/12693-1.

\section{REFERENCES}

ANGUlO, R. J.; SOUZA, M. C.; REIMER, P. J.; SASAOKA, S. K. Reservoir effect of the southern and southeastern Brazilian coast. Radiocarbon, v. 47, p. 67 73. 2005.

ANGUlO, R.; LESSA, G. C.; SOUZA, M. C. A critical review of mid- to late-Holocene sea-level fluctuations on the eastern Brazilian coastline. Quat. Sci. Rev., v. 25, p. 486-506. 2006.

ARZ, H. W.; PÄTZOLD, J.; WEFER, G. Correlated Millennial-Scale Changes in Surface Hydrography and Terrigenous Sediment Yield Inferred from Last-Glacial arine Deposits off Northeastern Brazil. Quat. Res., v. 50, p. 157-166. 1998.

BARBOSA, V. P. Foraminíferos Bentônicos Quaternários do talude continental da Bacia de Santos: Sistemática, Paleobatimetria e Paleoecologia. 1998. 427 p. Dissertação de Mestrado - Instituto de Geociências, Universidade Federal do Rio Grande do Sul, Rio Grande, RS., 1998.

BROECKER, W. S.; PENG, T.-H. Carbon cycle: 1985Glacial to interglacial changes in the operation of the global carbon cycle. Radiocarbon, v. 28, p. 309-327, 1986.

CAMPOS, E. J. D.; VELHOTE, D; SILVEIRA, I. C. A. Shelf break upwelling driven by Brazil Current cyclonic meanders. Geophys. Res. Letts, v. 27, n. 6, p. 751-754, 2000.

CASTRO, B. M. Correntes e massas de água da plataforma continental norte de São Paulo. 1996. 248 p. Tese de livre-docência - Instituto Oceanográfico, Universidade de São Paulo, São Paulo, SP, 1996.
CLAUZET, G.; WAINER, I.; LAZAR, A.; BRADY, E.; OTTO-BLIESNER, B.. A numerical study of the South Atlantic circulation at the Last Glacial Maximum. Palaeogeogr. Palaeoclimatol. Palaeoecol., v. 253, p. 509-528, 2007.

CORRÊA, I. C. S. Les variations du niveau de la mer durant les derniers 17500 ans BP: l'exemple de la plate-forme continentale du Rio Grande do Sul - Brésil. Mar. Geol., v. 130, p. 163-178, 1996.

EBERWEIN, A.; MACKENSEN, A. Last Glacial Maximum paleoproductivity and water masses off NW-Africa: Evidence from benthic foraminifera and stable isotopes. Mar. Micropal., v. 67, p. 87-103, 2008.

FONTANIER, C.; JORISSEN, F. J.; LICARI, L.; ANSCHUTZ, A.; CARBONEL, P. Live benthic foraminiferal faunas from the Bay of Biscay: faunal density, composition, and microhabitats. Deep-Sea Res. I, v. 49, p.751-785, 2002.

GIANNINI, P. C. F.; SAWAKUCHI, A. O.; MARTINHO, C. T.; TATUMI, S. H. Eolian depositional episodes controlled by Late Quaternary relative sea level changes on the Imbituba-Laguna coast (southern Brazil). Mar. Geol., v. 237, p.143-168, 2007.

HEMLEBEN, C.; SPINDLER, M.; EERSON, O. R. Modern planktonic foraminifera. New York: Springer-Verlag, 1989. 363 p.

HERGUERA, J. C.; BERGER, W. H. Paleoproductivity from benthic foraminifera abundance; glacial to postglacial change in the west-equatorial Pacific. Geology, v. 19, p. 1173-1176, 1991.

JACOB, J.; HUANG, Y.; DISNAR, J.-R.; SIFEDDINE, A.; BOUSSAFIR, M., ALBUQUERQUE, A. L. S.; TURCQ, B. Paleohydrological changes during the last deglaciation in Northern Brazil. Quat. Sci. Rev., v. 26, p.1004-1015, 2007.

JONES, R. W. The Challenger foramifera. London: Oxford Science Publications; The Natural History Museum; Oxford University Press, 1994.149 p.

KEMLE-VON MÜCKE, S.; HEMLEBEN, C. Foraminifera. In: BOLTOVSKOY, D. (Ed.). South Atlantic Zooplankton. Leiden: Backhuys Publishers, 1999. p. 4373.

LEDRU, M.-P.; ROUSSEAU, D.-D.; CRUZ JR., F. W.; RICCOMINI, C.; KARMANN, I.; MARTIN, L. Paleoclimate changes during the last $100000 \mathrm{yr}$ from a record in the Brazilian Atlantic rainforest region and interhemispheric comparison. Quat. Res., v. 64, p. 444 450, 2005.

LOEBLICH JR., A. R.; TAPPAN, H. Foraminiferal genera and their classification - PLATES. New York: Van Nostrand Reinhold, 1988. 2 v. 970 p.

LOUBERE, P.; FARIDUDDIN, M. Benthic Foraminifera and the Flux of Organic Carbon to the Seabed. In: SEN GUPTA, B. K. (Ed.). Modern Foraminifera. London:Kluwer Academic Press, 1999. p.181-200.

MACKENSEN, A.; SCHMIELD, G.; HARLOFF, J.; GIESE, M. Deep-sea foraminifera in the South Atlantic Ocean: Ecology and assemblage generation. Mar. Micropal., v.41, p. 342-358. 1995.

MAHIQUES, M. M.; MISHIMA Y.; RODRIGUES, M. Characteristics of the sedimentary organic matter on the inner and middle continental shelf between Guanabara Bay and São Francisco do Sul, eastern Brazilian margin. Cont. Shelf Res., v.19, p.775- 798, 1999. 
MAHIQUES, M. M.; SILVEIRA, I. C. A.; SOUSA, S. H. M.; RODRIGUES, M. Post-LGM sedimentation on the outer shelf-upper slope of the northermost part of São Paulo Bight, southeastern Brazil. Mar. Geol., v.181, p. 387-400, 2002.

MAHIQUES, M. M.; TESSLER, M. G.; CIOTTI, A. M.; SILVEIRA, I. C. A.; SOUSA, S. H. M.; FIGUEIRA, R. L.; TASSINARI, C. C. G.; FURTADO, V. V.; PASSOS, R.F. Hydrodynamically-driven patterns of recent sedimentation in the shelf and upper slope off southeast Brazil. Cont. Shelf Res., v. 24, p. 1685-1697, 2004.

MAHIQUES, M. M.; FUKUMOTO, M. M.; SILVEIRA, I. C. A.; FIGUEIRA, R. C. L.; BÍCEGO, M. C.; LOURENÇO, R.A.; SOUSA, S.H.M. Sedimentary changes on the Southeastern Brazilian upper slope during the last 35000 years. An. Acad. Bras. Cienc., v.79, n. 1, p. 171-181, 2007.

MARTIN, L.; SUGUIO, K.; FLEXOR, J. N. Hauts niveaux marins pleistocenes du litoral bresilien. Palaeogeogr. Palaeoclimatol. Palaeoecol., v. 68, n. 3, p. 231-239, 1988.

MARTINS , V.; DUBERT, J.; JOUANNEAU , J.; WEBER, O.; SILVA, E. F.; PATINHA, C.; DIAS, J. M. A.; ROCHA, F. A multiproxy approach of the Holocene evolution of shelf-slope circulation on the NW Iberian Continental Shelf. Mar. Geol., v. 239, p.1-18, 2007.

MIX, A. C. Influence of productivity variations on long-term atmospheric CO2 . Nature, v.337, p. 541-544, 1989.

MIX, A. C.; BARD, E.; SCHNEIDER, R. Environmental processes of the ice age: land, oceans, glaciers (EPILOG). Quat. Sci. Rev., v.20, p.627-657, 2001.

MOLLENHAUER, G.; SCHNEIDER, R. R.; JENNERJAHN, T.; MÜLLER, P. J.; WEFER, G. Organic carbon accumulation in the South Atlantic Ocean: its modern, mid-Holocene and last glacial distribution. Glob. Planet. Change, v. 40, p. 249-266, 2004.

MOREY, A. E.; MIX, A. C.; PISIAS, N. G. Planktonic foraminiferal assemblages preserved in surface sediments correspond to multiple environmental variables. Quat. Sci. Rev., v. 24, p. 925-950, 2005.

MURRAY, J.W. Ecology and palaeoecology of benthic foraminifera. New York: Longman Scientific \& Technical, 1991. 397 p.

SARNTHEIN, M.; WINN, K.; DUPLESSY, J.-C.; FONTUGNE, M.R. Global variations of surface ocean productivity in low and mid latitudes: Influence on $\mathrm{CO}_{2}$ reservoirs of the deep ocean and atmosphere during the last 21,000 years. Paleoceanography, v.3, n. 3, p. 361399, 1988

SCHMIEDL, G.; MACKENSEN, A. Late Quaternary paleoproductivity and deep water circulation in the eastern South Atlantic Ocean: Evidence from benthic foraminifera. Palaeogeogr. Palaeoclimatol. Palaeoecol., v. 130 , p. $43-80,1997$.
SCHMIEDL, G.; DE BOVÉE, F.; BUSCAIL, R.; CHARRIÈRE, B.; HEMLEBEN, C.; MEDERNACH, L.; PICON, P. Trophic control of benthic foraminiferal abundance and microhabitat in the bathyal Gulf of Lions, western Mediterranean Sea. Mar. Micropal., v. 40, n. 3, p.167-188, 2000.

SILVEIRA, I. C. A.; SCHIMIDT, A. C. K.; CAMPOS, E. J. D.; GODOI, S. S.; IKEDA, Y. A Corrente do Brasil ao largo da costa Leste Brasileira. Rev. Bras. Oceanogr., v. 48, n. 2, p. $171-183,2000$.

SYLVESTRE, F. Moisture Pattern During the Last Glacial Maximum in South America. In: VIMEUX F. et al. (Ed.). Past climate variability in South America and surrounding regions: From the Last Glacial Maximum to the Holocene, v. 14: Developments in Paleoenvironmental Research. New York: SpringerVerlag, 2009, p. 3-28.

TOLEDO, F. A. L.; CACHÃO, M.; COSTA, K. B.; PIVEL, M. A. G. Planktonic foraminifera, calcareous nannoplankton and ascidian variations during the last 25 kyr in the Southwestern Atlantic: A paleoproductivity signature? Mar. Micropaleont., v. 64, p.67-79, 2007a.

TOLEDO, F. A. L., COSTA, K. B., PIVEL, M. A. G. Salinity changes in the western tropical South Atlantic during the last 30 kyr. Glob. Planet. Change, v.57, p.383-395, 2007b.

TOLEDO, F. A. L.; COSTA, K. B.; PIVEL, M. A. G.; CAMPOS, E. J. D. Tracing past circulation changes in the western south Atlantic based on planktonic foraminifera. Rev. Bras. Paleontol., v. 11, n. 3, p.169178. 2008.

VAN MORKHOVEN, F. P. C. M.; BERGGREN, W. A.; EDWARDS, A. S. Cenozoic cosmopolitan deep-water benthic foraminifera. Bull. Cent. Rech. Explor.-Prod. Elf- Aquitaine, 421 p., 1986.

VIANA, A. R.; FAUGÈRES, J.-C.; STOW, D. A. V. Bottomcurrent-controlled sand deposits - a review of modern shallow- to deep-water environments. Sedim. Geo., v. 115, p. 133-157, 1998.

WOLLENBURG, J. E.; KUHNT, W. The response of benthic foraminifers to carbon flux and primary production in the Arctic Ocean. Mar. Micropal., v. 40, p. 189-231, 2000.

ZEMBRUSCKI, S. G. Geomorfologia da margem continental sul brasileira e das bacias oceânicas adjacentes. In: CHAVES, H. A. F. (Ed.). Geomorfologia da margem continental brasileira e das bacias oceânicas adjacentes. Rio de Janeiro: PETROBRAS-CENPESDINTEP BRAZIL, 1979. Série Projeto REMAC, v. 7, p. 129-177. 
Appendix - Along-core distribution of representative benthic foraminifera species densities (tests·cm-3). (Supplementary data, available online only).

\begin{tabular}{|c|c|c|c|c|c|c|c|c|c|c|c|c|c|c|c|c|}
\hline 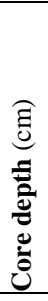 & 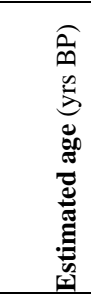 & 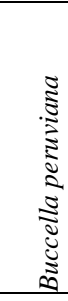 & 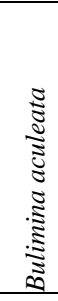 & 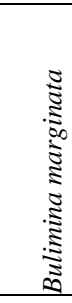 & 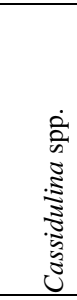 & 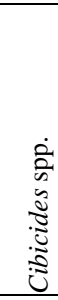 & 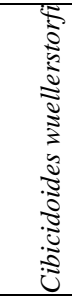 & 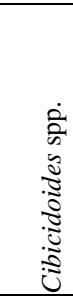 & 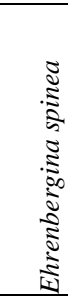 & 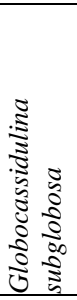 & 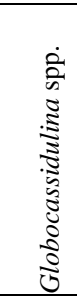 & 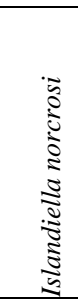 & 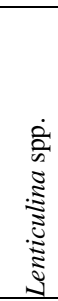 & 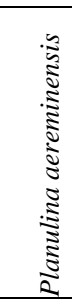 & 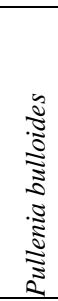 & 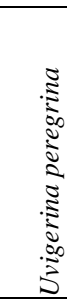 \\
\hline 0 & 2840 & 384 & 0 & 1664 & 3584 & 640 & 6528 & 0 & 1024 & 6144 & 1280 & 6528 & 128 & 9984 & 256 & 3200 \\
\hline 4 & 6095 & 0 & 0 & 6912 & 5888 & 0 & 6400 & 2560 & 2304 & 8448 & 5120 & 5888 & 256 & 9472 & 256 & 5632 \\
\hline 10 & 10980 & 256 & 0 & 3712 & 3968 & 256 & 9856 & 896 & 1024 & 3584 & 3200 & 2560 & 0 & 8448 & 128 & 3584 \\
\hline 14 & 14230 & 128 & 0 & 5248 & 1792 & 128 & 6272 & 0 & 1152 & 4224 & 1792 & 3584 & 0 & 4736 & 256 & 3456 \\
\hline 20 & 19110 & 256 & 0 & 1952 & 1888 & 160 & 2144 & 288 & 224 & 2304 & 640 & 2592 & 32 & 2656 & 0 & 2208 \\
\hline 22 & 19825 & 384 & 128 & 1920 & 1216 & 64 & 3584 & 768 & 832 & 2368 & 960 & 3008 & 64 & 3200 & 128 & 1984 \\
\hline 24 & 20540 & 192 & 0 & 1344 & 896 & 0 & 2112 & 0 & 256 & 1408 & 1024 & 1664 & 64 & 2048 & 64 & 1216 \\
\hline 26 & 20723 & 512 & 0 & 2560 & 1920 & 0 & 3968 & 1280 & 1664 & 3584 & 1152 & 6016 & 0 & 5760 & 0 & 0 \\
\hline 28 & 20906 & 1024 & 0 & 5120 & 1280 & 128 & 4992 & 2048 & 896 & 4096 & 2048 & 8576 & 0 & 6144 & 0 & 3072 \\
\hline 30 & 21090 & 0 & 128 & 640 & 544 & 0 & 2080 & 0 & 288 & 1248 & 672 & 1920 & 64 & 1184 & 0 & 1312 \\
\hline 32 & 21275 & 32 & 0 & 896 & 160 & 0 & 576 & 288 & 96 & 1152 & 448 & 1280 & 0 & 800 & 32 & 800 \\
\hline 34 & 21460 & 0 & 8 & 72 & 264 & 0 & 304 & 0 & 24 & 88 & 48 & 352 & 16 & 320 & 0 & 224 \\
\hline 36 & 21640 & 32 & 64 & 1184 & 192 & 64 & 896 & 256 & 0 & 896 & 512 & 1824 & 0 & 1184 & 0 & 960 \\
\hline 38 & 21820 & 32 & 24 & 224 & 88 & 0 & 208 & 96 & 72 & 272 & 64 & 392 & 0 & 344 & 0 & 280 \\
\hline 40 & 22000 & 88 & 0 & 464 & 216 & 96 & 408 & 8 & 32 & 280 & 144 & 440 & 8 & 408 & 0 & 296 \\
\hline 42 & 22180 & 32 & 32 & 528 & 176 & 16 & 752 & 96 & 64 & 544 & 160 & 576 & 0 & 496 & 0 & 368 \\
\hline 44 & 22360 & 0 & 0 & 240 & 88 & 0 & 144 & 136 & 72 & 216 & 184 & 184 & 0 & 296 & 0 & 120 \\
\hline 46 & 22543 & 8 & 24 & 304 & 160 & 0 & 456 & 0 & 88 & 280 & 152 & 456 & 0 & 312 & 0 & 216 \\
\hline 48 & 22726 & 64 & 0 & 120 & 112 & 8 & 344 & 88 & 96 & 248 & 120 & 616 & 8 & 320 & 16 & 224 \\
\hline 50 & 22910 & 0 & 0 & 272 & 128 & 24 & 272 & 40 & 72 & 144 & 88 & 344 & 8 & 176 & 8 & 120 \\
\hline 52 & 23090 & 40 & 8 & 352 & 128 & 0 & 192 & 72 & 24 & 64 & 120 & 248 & 0 & 192 & 0 & 200 \\
\hline 54 & 23270 & 0 & 1 & 31 & 6 & 0 & 50 & 0 & 3 & 32 & 9 & 28 & 2 & 35 & 11 & 43 \\
\hline 56 & 23453 & 3 & 0 & 18 & 18 & 1 & 22 & 3 & 4 & 19 & 9 & 53 & 0 & 0 & 0 & 18 \\
\hline 58 & 23636 & 1 & 0 & 29 & 14 & 1 & 34 & 3 & 6 & 24 & 23 & 39 & 0 & 35 & 0 & 17 \\
\hline 60 & 23820 & 1 & 7 & 18 & 2 & 17 & 20 & 0 & 5 & 28 & 21 & 18 & 1 & 38 & 0 & 30 \\
\hline 62 & 23838 & 256 & 128 & 1664 & 576 & 64 & 1344 & 384 & 704 & 1984 & 1344 & 2304 & 0 & 2368 & 64 & 1536 \\
\hline 64 & 24180 & 2 & 0 & 23 & 17 & 0 & 6 & 12 & 4 & 15 & 7 & 26 & 3 & 23 & 18 & 9 \\
\hline 66 & 24363 & 3 & 3 & 105 & 60 & 3 & 78 & 43 & 35 & 98 & 68 & 93 & 0 & 115 & 3 & 65 \\
\hline 68 & 24546 & 32 & 0 & 200 & 32 & 0 & 144 & 112 & 72 & 200 & 176 & 272 & 8 & 328 & 0 & 200 \\
\hline 70 & 24730 & 0 & 0 & 83 & 60 & 5 & 68 & 23 & 15 & 55 & 80 & 70 & 5 & 118 & 0 & 50 \\
\hline 74 & 25090 & 0 & 0 & 92 & 36 & 0 & 96 & 0 & 28 & 116 & 36 & 64 & 12 & 160 & 12 & 84 \\
\hline 80 & 25640 & 2 & 12 & 24 & 0 & 3 & 0 & 0 & 0 & 12 & 0 & 57 & 1 & 16 & 0 & 0 \\
\hline 84 & 26000 & 0 & 0 & 30 & 2 & 0 & 0 & 3 & 1 & 6 & 3 & 22 & 1 & 6 & 0 & 15 \\
\hline 90 & 26550 & 0 & 0 & 34 & 12 & 0 & 29 & 0 & 4 & 15 & 10 & 32 & 6 & 39 & 0 & 17 \\
\hline 92 & 26730 & 1 & 1 & 16 & 12 & 0 & 8 & 7 & 3 & 10 & 14 & 33 & 1 & 15 & 1 & 9 \\
\hline 94 & 26910 & 0 & 5 & 23 & 9 & 1 & 2 & 2 & 1 & 16 & 3 & 31 & 0 & 13 & 0 & 12 \\
\hline
\end{tabular}

